\title{
FENOLOGI DAN ANALISA PERTUMBUHAN DUA VARIETAS KACANG PANJANG (Vigna sinensis L.) BERDASAR KONSEP AKUMULASI PANAS
}

\section{PHENOLOGY AND GROWTH ANALYSIS OF TWO VARIETIES LONG BEAN (Vigna sinensis L.) BASED ON THE CONCEPT OF ACCUMULATED HEAT}

\author{
Rima Melati ${ }^{1}$ \\ ${ }^{1)}$ Agriculture Faculty of Khairun University \\ Jl. Kampus 2 Gambesi- Ternate Selatan, Ternate
}

\begin{abstract}
An understanding of plant growth analysis can be assessed based on the ratio of accumulated heat and not a day of planting. This comparison is intended to find the relationship of heat received by the plants that accumulate with the analysis of accelerated growth. Indicator amount of heat obtained from the daily temperate at several different locations. The purpose of this study was to determine differences in the growth of two varieties of long beans at altitude of different places on the historical accumulation of heat. This research was conducted in a field using census sampling methods at three study sites are in the village Dinoyo with altitude $450 \mathrm{~m}$ asl, in the village Bumiaji with $800 \mathrm{~m}$ asl, and Junggo with $1200 \mathrm{~m}$ asl. Heat accumulation of research data were analyzed using linear regression followed by a t-test on $95 \%$ confidence level, while the analysis of plant growth using a mathematical calculation on the observation of Relative Growth Rate ( $\mathrm{RGR}_{\mathrm{GDD}}$ ), Net Assimilation Rate (NAR GDD). The result showed that the average value of Relative Growth Rate $\left(\mathrm{RGR}_{\mathrm{GDD}}\right)$ the two varieties decreased along with increasing accumulation of heat collected at each observation interval. The average value of Net Assimilation Rate (NAR ${ }_{\text {GDD }}$ ) both varieties increated along with increasing the value of thee accumulated heat.
\end{abstract}

Keyword: long bean, heat accumulation, growth

\begin{abstract}
Abstrak: Pemahaman terhadap analisa pertumbuhan tanaman dapat dikaji berdasarkan perbandingan akumulasi panas dan bukan hari tanam. Perbandingan ini dimaksudkan untuk mencari hubungan panas yang diterima oleh tanaman yang terakumulasi dengan analisa percepatan pertumbuhan. Indikator sejumlah panas diperoleh dari suhu harian di beberapa lokasi yang berbeda. Tujuan penelitian ini adalah mengetahui perbedaan pertumbuhan dua varietas kacang panjang di ketinggian tempat yang berbeda berdasarkan konsep akumulasi panas. Penelitian ini dilakukan di lapang yang menggunakan metode sampling sensus di tiga lokasi penelitian yaitu di kelurahan Dinoyo dengan ketingggian $450 \mathrm{~m} \mathrm{dpl}$, Bumiaji $800 \mathrm{~m}$ dpl dan dusun Junggo $1200 \mathrm{~m}$ dpl. Data penelitian akumulasi panas dianalisa menggunakan regresi linear yang dilanjutkan dengan uji-tpada tingkat kepercayaan $95 \%$, sedangakan analisa pertumbuhan tanaman menggunakan perhitungan matematik pada pengamatan LajuPertumbuhanRelatif $\left(\mathrm{RGR}_{\mathrm{GDD}}\right)$, lajuasimilasibersih $\left(\mathrm{NAR}_{\mathrm{GDD}}\right)$. Hasil penelitian menunjukkan bahwa nilai rata-rata laju pertumbuhan relatif $\left(\mathrm{RGR}_{\mathrm{DD}}\right)$ kedua varietas menurun bersamaan dengan peningkatan akumulasi panas yang terkumpul di setiap interval pengamatan. Nilai rata-rata lajuasimilasibersih(NAR $\mathrm{DD}_{\mathrm{DD}}$ ) kedua varietas meningkat bersamaan dengan bertambahnya nilai akumulasi panas.
\end{abstract}

Kata Kunci: kacang Panjang, akumulasi panas, pertumbuhan 